\title{
Dimethylthiourea protects against chlorine induced changes in airway function in a murine model of irritant induced asthma
}

\author{
Toby K McGovern', William S Powell', Brian J Day², Carl W White², Karuthapillai Govindaraju', \\ Harry Karmouty-Quintana', Normand Lavoie', Ju Jing Tan', James G Martin ${ }^{1 *}$
}

\begin{abstract}
Background: Exposure to chlorine $\left(\mathrm{Cl}_{2}\right)$ causes airway injury, characterized by oxidative damage, an influx of inflammatory cells and airway hyperresponsiveness. We hypothesized that $\mathrm{Cl}_{2}$-induced airway injury may be attenuated by antioxidant treatment, even after the initial injury.
\end{abstract}

Methods: Balb/C mice were exposed to $\mathrm{Cl}_{2}$ gas (100 ppm) for 5 mins, an exposure that was established to alter airway function with minimal histological disruption of the epithelium. Twenty-four hours after exposure to $\mathrm{Cl}_{2 \text {, }}$ airway responsiveness to aerosolized methacholine (MCh) was measured. Bronchoalveolar lavage (BAL) was performed to determine inflammatory cell profiles, total protein, and glutathione levels. Dimethylthiourea (DMTU;100 mg/kg) was administered one hour before or one hour following $\mathrm{Cl}_{2}$ exposure.

Results: Mice exposed to $\mathrm{Cl}_{2}$ had airway hyperresponsiveness to MCh compared to control animals pre-treated and post-treated with DMTU. Total cell counts in BAL fluid were elevated by $\mathrm{Cl}_{2}$ exposure and were not affected by DMTU treatment. However, DMTU-treated mice had lower protein levels in the BAL than the $\mathrm{Cl}_{2}$-only treated animals. 4-Hydroxynonenal analysis showed that DMTU given pre- or post-Cl 2 prevented lipid peroxidation in the lung. Following $\mathrm{Cl}_{2}$ exposure glutathione (GSH) was elevated immediately following exposure both in BAL cells and in fluid and this change was prevented by DMTU. GSSG was depleted in $\mathrm{Cl}_{2}$ exposed mice at later time points. However, the GSH/GSSG ratio remained high in chlorine exposed mice, an effect attenuated by DMTU.

Conclusion: Our data show that the anti-oxidant DMTU is effective in attenuating $\mathrm{Cl}_{2}$ induced increase in airway responsiveness, inflammation and biomarkers of oxidative stress.

\section{Introduction}

Respiratory health is adversely affected by exposure to strong irritant substances such as chlorine $\left(\mathrm{Cl}_{2}\right)$ or ozone [1]. A single, acute exposure of persons to $\mathrm{Cl}_{2}$ in an industrial or domestic context may trigger asthma in a proportion of those exposed and is termed irritantinduced asthma [2,3]. High dose exposures may lead to acute lung injury and death [4]. Although the mechanism of the induction of asthma by irritants is uncertain, this form of asthma may be a significant contributor to the current rising prevalence of this disease. Some of

\footnotetext{
* Correspondence: james.martin@mcgill.ca

'Meakins Christie Laboratories, Department of Medicine, McGill University, Montreal, Quebec, Canada

Full list of author information is available at the end of the article
}

the irritants that induce symptoms of asthma such as ozone and $\mathrm{Cl}_{2}$ cause oxidant injury, in particular to the airway epithelium. Desquamation of the airway epithelium and prolonged sub-epithelial inflammation accompanied by airway hyperresponsiveness has been documented following a single acute $\mathrm{Cl}_{2}$ inhalational exposure [5]. Epithelial shedding may adversely affect barrier function of the epithelium and may diminish the influence of epithelial-derived bronchodilator substances such as nitric oxide [6]. $\mathrm{Cl}_{2}$ is a highly reactive substance and has been documented to cause airway injury in mice that is associated with oxidant stress, as evidenced by the finding of peroxynitrite in the airway tissues and carbonylation of proteins [7]. There may be additional contributions to oxidant injury through
C Biomed Central

(c) 2010 McGovern et al; licensee BioMed Central Ltd. This is an Open Access article distributed under the terms of the Creative Commons Attribution License (http://creativecommons.org/licenses/by/2.0), which permits unrestricted use, distribution, and reproduction in any medium, provided the original work is properly cited. 
activation of inflammatory cells [8]. The causative role of oxidative stress in the changes in airway function and airway inflammation caused by a potent oxidant like $\mathrm{Cl}_{2}$ is relatively under-investigated. Recently a combination of anti-oxidants (ascorbic acid, desferroxamine and $\mathrm{N}$-acetylcysteine) was found to attenuate signs of respiratory dysfunction, in particular gas exchange and microvascular leak, in the rat [9].

The current study was designed to examine the relationship between oxidant damage, airway hyperresponsiveness and inflammation caused by $\mathrm{Cl}_{2}$ by testing the efficacy of an anti-oxidant in protecting against these effects. For this purpose we used dimethylthiourea (DMTU), an oxygen metabolite scavenger [10], that is highly cell-permeable [11-13]. We also wished to examine the effects of $\mathrm{Cl}_{2}$ on markers of oxidative stress and whether DMTU attenuated these effects. We hypothesized that treatment with DMTU would ameliorate the inflammatory and pathophysiological effects induced by $\mathrm{Cl}_{2}$ gas exposure whether administered before or after exposure.

\section{Methods}

\section{Animals and protocol}

Male Balb/C mice (18-22 g) were purchased from Charles River (Wilmington, Massachusetts) and housed in a conventional animal facility at McGill University. Animals were treated according to guidelines of the Canadian Council for Animal Care and protocols were approved by the Animal Care Committee of McGill University.

Mice were exposed to either room air (control) or $\mathrm{Cl}_{2}$ gas diluted in room air for 5 minutes using a nose-only exposure chamber. An initial experiment was performed to assess an exposure level required to effect changes in airway responsiveness to methacholine $(\mathrm{MCh})$ that was well tolerated by the animals. For this purpose we exposed mice to 100,200 or $400 \mathrm{ppm} \mathrm{Cl}_{2}$, and 24 hours later we performed $\mathrm{MCh}$ challenge and removed the lungs for histological analysis. Based on the results of this experiment we tested the effects of DMTU on animals exposed to $100 \mathrm{ppm} \mathrm{Cl}_{2}$. The control mice were exposed to room air (Control; $\mathrm{n}=6$ ) and test mice were exposed to $\mathrm{Cl}_{2}\left(\mathrm{Cl}_{2} ; 100 \mathrm{ppm} ; \mathrm{n}=6\right)$ with DMTU $(100 \mathrm{mg} / \mathrm{kg})$ treatment intraperitoneally either one hour before (DMTU/Cl $\mathrm{D}_{2} ; \mathrm{n}=6$ ) or one hour after $\mathrm{Cl}_{2}$ exposure $\left(\mathrm{Cl}_{2} /\right.$ DMTU; $n=6)$. DMTU was prepared fresh prior to each exposure and a dose of $100 \mathrm{mg} / \mathrm{kg}$ in $500 \mu \mathrm{L}$ of sterile phosphate buffered saline (PBS) was administered i.p. either one hour before or one hour following exposure to $\mathrm{Cl}_{2}$. Control (air exposed) mice received $500 \mu \mathrm{L}$ PBS i.p and $\mathrm{Cl}_{2}$ exposed mice received $500 \mu \mathrm{L}$ PBS i.p. either one hour before or one hour following exposure. We chose the dose of DMTU based on previous observations of efficacy against an oxidant pollutant in mice [11]. At 24 hours after $\mathrm{Cl}_{2}$ exposure, lung function measurements including responsiveness to aerosolized MCh were performed and bronchoalveolar lavage fluid was obtained for assessment of inflammatory cell counts, total protein, nitrate/nitrite (nitric oxide) and glutathione levels. The lungs were removed for analysis of carbonylated proteins and 4-hydroxynonenal (4-HNE). Measurements of inflammatory cell counts and glutathione levels in BAL fluid were made also at $10 \mathrm{~min}$ and at $1 \mathrm{hr}$ after $\mathrm{Cl}_{2}$. Following exposure animals were returned to the animal facility and allowed food and water ad libitum.

\section{Exposure to $\mathrm{Cl}_{2}$}

Mice were restrained and exposed to $\mathrm{Cl}_{2}$ gas for $5 \mathrm{~min}$ utes using a nose-only exposure device. $\mathrm{Cl}_{2}$ gas was mixed with room air using a standardized calibrator (VICI Metronics, Dynacalibrator ${ }^{\oplus}$, model 230-28A). The $\mathrm{Cl}_{2}$ delivery system has two main components, a gas generator, which includes a heated permeation chamber and air flow generator. Dynacal permeation tubes designed specifically for operation with the Dynacalibrator were used and contain the $\mathrm{Cl}_{2}$. The permeation chamber and air flow generator control accuracy of the $\mathrm{Cl}_{2}$ generated to within $1-3 \%$ of the desired concentration (manufacturer's specifications). Within the gas chamber, permeation tubes containing $\mathrm{Cl}_{2}$ are housed for gas delivery. The Teflon permeation tubes contain $\mathrm{Cl}_{2}$ in both gas and liquid phases. When the tube is heated the $\mathrm{Cl}_{2}$ reaches a constant and increased vapor pressure and it permeates the tube at a constant rate. The desired concentration is delivered at an appropriate flow rate, as specified by the manufacturer. The device is attached to the exposure chamber and allowed to calibrate for 30 minutes until the optimum temperature of $30^{\circ} \mathrm{C}$ is reached and the $\mathrm{Cl}_{2}$ flow is constant. Following removal of the animals from the exposure chamber, the chamber was continually flushed with the gas mix to ensure that the desired concentration of $\mathrm{Cl}_{2}$ was maintained.

\section{Evaluation of Respiratory Responsiveness}

Mice were sedated with an intraperitoneal (i.p) injection of xylazine hydrochloride $(8 \mathrm{mg} / \mathrm{kg})$ and anaesthetized with $\mathrm{i}$. p. injection of pentobarbital ( $30 \mathrm{mg} / \mathrm{kg}$ ). Subsequently, the animal was tracheostomized using at 18 gauge cannula and connected to a small animal ventilator (FlexiVent, Scireq, Montreal, Canada). Muscle paralysis was induced with pancuronium bromide $(0.2 \mathrm{mg} / \mathrm{kg}$ i.p.). The mice were ventilated in a quasi-sinusoidal fashion with the following settings: a tidal volume of $10 \mathrm{~mL} / \mathrm{kg}$, maximum inflation pressure of $30 \mathrm{cmH}_{2} 0$, a positive end expiratory pressure (PEEP) of $3 \mathrm{cmH}_{2} \mathrm{O}$ and a frequency of $150 / \mathrm{min}$. Following an equilibration period of 3 minutes of tidal ventilation two lung inflations to a transrespiratory pressure of $25 \mathrm{~cm}$ 
$\mathrm{H}_{2} \mathrm{O}$ were performed and baseline measurements were taken. The respiratory mechanics were estimated using a single compartment model and commercial software (Scireq). Baseline was established as the average of three perturbations. Following establishment of baseline, $\mathrm{MCh}$ was administered using an in-line nebulizer (Aeroneb Lab, standard mist model, Aerogen Ltd, Ireland) and progressively doubling concentrations ranging from 6.25 to 50 $\mathrm{mg} / \mathrm{ml}$ were administered over 10 seconds synchronously with inspiration. Six perturbations were calculated at each dose of MCh to establish the peak response. The highest value was kept for analysis subject to a coefficient of determination above 0.85 . Respiratory system resistance (Rrs) and respiratory system elastance (Edyn) were determined before challenge and after each dose of $\mathrm{MCh}$.

\section{Bronchoalveolar Lavage Fluid Analysis}

Following euthanasia (60 $\mathrm{mg} / \mathrm{kg}$ pentabarbital, i.p.), the lungs were lavaged with $600 \mu \mathrm{l}$ of sterile saline, followed by four separate aliquots of $1 \mathrm{ml}$ each as previously described [7]. The first $600 \mu \mathrm{lmL}$ aliquot of BAL fluid was centrifuged at $1500 \mathrm{rpm}$ for 5 minutes at $4^{\circ} \mathrm{C}$ and the supernatant was retained for measurements of nitric oxide, glutathione levels and protein levels using a Bradford Assay. The separate $1 \mathrm{~mL}$ aliquots were spun at $1500 \mathrm{rpm}$ for $5 \mathrm{~min}$ at $4^{\circ} \mathrm{C}$ and the supernatant removed. The cell pellets were pooled for differential cell counts using $100 \mu \mathrm{l}$ of the re-suspended cells. Cytospins were prepared, air-dried and stained (Diff-Quik ${ }^{\bullet}$ method, Medical Diagnostics, Düdingen, Germany). A differential cell count was determined on a minimum of 300 cells.

\section{Histology}

Following harvesting, the lungs were perfused with saline until the effluent was clear. The right lung was inflated with $1 \mathrm{~mL} 10 \%$ buffered formalin, fixed overnight with formalin. Tissues were embedded in paraffin blocks, cut into $5 \mu \mathrm{m}$ sections and stained with hematoxylin and eosin. Sections were evaluated for epithelial morphological changes. The absolute number of epithelial cells in the airways was determined by counting cells on hematoxylin and eosin stained slides at $200 \times$ magnification and data were expressed as the number of epithelial cells per $\mathrm{mm}$ of basement membrane perimeter $\left(\mathrm{P}_{\mathrm{BM}}\right)$. Epithelial cell height was determined by measuring the distance between the basement membrane and the top of the epithelial cell in the four quadrants for each airway and averaged.

\section{Measurement of Nitrite/Nitrate in BAL}

For the evaluation of nitric oxide, $0.6 \mathrm{~N}$ trichloroacetic acid was added to the supernatant of the BAL fluid to give a final concentration of $0.12 \mathrm{~N}$ to precipitate any protein. Samples were centrifuged for 10 minutes at
10,000 RPM followed by removal of the supernatant for analysis using previously described methods [7]. Total $\mathrm{NO}_{x}$ was measured in BAL as an index of NO production using the Griess reaction. Briefly, $80 \mu \mathrm{l}$ of sample were pre-incubated with $20 \mu \mathrm{l}$ of $\mathrm{NO}_{3}$ reductase and 10 $\mu \mathrm{l}$ of its enzyme cofactor for $3 \mathrm{~h}$ at room temperature and then incubated with $100 \mu$ lof Griess reagent for 10 min. $\mathrm{NO}_{\mathrm{x}}$ concentrations were determined using standard curves obtained from different concentrations of $\mathrm{NaNO}_{2}$ or $\mathrm{NaNO}_{3}$. Absorbance was measured at 540 $\mathrm{nm}$ with a plate reader (SLT 400 ATC; SLT Lab Instruments, Salzburg, Austria). No $\mathrm{NO}_{\mathrm{x}}$ was detected in saline solutions using this assay.

\section{Carbonylated protein residues (Oxyblot)}

An Oxyblot was performed on left lung tissue extracts taken 24 hours following $\mathrm{Cl}_{2}$ challenge. Extracted proteins were denatured with $12 \%$ sodium dodecylsulfate (SDS) before derivatization with the addition of DNPH (2,4-dinitrophenylhydrazone-hydrazone). DNPHderivatised proteins were separated on a $10 \%$ SDS-PAGE gel at $140 \mathrm{~V}$ for $2 \mathrm{~h}$. Proteins were then electrophoretically transferred onto polyvinylidene difluoride (PVDF) membrane with $11.6 \mathrm{mM}$ Tris (Fisher), $95.9 \mathrm{mM}$ glycine (Fisher) and 20\% methanol (Fisher) at $25 \mathrm{~V}$ for $2 \mathrm{~h}$. Membranes were then blocked with $1 \%$ bovine serum albumin-TTBS solution (0.02 M Tris base, $0.5 \mathrm{M} \mathrm{NaCl}$, and $0.1 \%$ of Tween 20; Sigma) and were probed for 90 min with rabbit anti-DNP antibody (Intergen Company, Purchase, NY). The membranes were then rinsed in TTBS and incubated with HRP-conjugated goat antirabbit IgG (Intergen Company, Purchase, NY) for $1 \mathrm{~h}$. A chemiluminescence detection system (ECL Plus; Amersham), Hyperfilm (Amersham), and Fluorochem 8000 software (Alpha Innotech Corporation, San Leandro, CA) were used for antibody detection and quantification by densitometry.

\section{Lung 4-hydroxynonenal (4-HNE) assay}

All reagents were from Sigma-Aldrich (St. Louis, MO, USA) unless otherwise stated. Frozen tissue, or a known amount of 4- HNE standard (Cayman Chemical, Ann Arbor, MI, USA), was placed in $2 \mathrm{ml}$ of cold methanol (Thermo Fisher) containing $50 \mu \mathrm{g} / \mathrm{ml}$ butylated hydroxytoluene, with $10 \mathrm{ng} \mathrm{d} 3-4-\mathrm{HNE}$ (Cayman Chemical) internal standard added just before homogenization with the Ultra-Turrax T25 (Thermo Fisher). An EDTA solution ( $1 \mathrm{ml}$ of $0.2 \mathrm{M}, \mathrm{pH} 7$ ) was added. Derivatization was accomplished by the addition of $0.2 \mathrm{ml}$ of $0.1 \mathrm{M}$ HEPES containing $50 \mathrm{mM}$ O-(2,3,4,5,6-pentafluorobenzyl)hydroxylamine hydrochloride, $\mathrm{pH}$ 6.5. The mixture was then vortexed and held at room temperature. After $5 \mathrm{~min}, 1 \mathrm{ml}$ of hexanes (Thermo Fisher) was added, and the samples were shaken vigorously. Brief centrifugation 
was performed to achieve phase separation and the O-pentafluorobenzyl-oxime derivatives were extracted from the upper hexane layer. The sample was dried under a stream of $\mathrm{N} 2$ gas and further derivatized into trimethylsilyl ethers by the addition of $15 \mu$ leach of pyridine and $\mathrm{N}, \mathrm{O}$ bis(trimethylsilyl)trifluoroacetamide. The samples were vortexed and heated to $80^{\circ} \mathrm{C}$ for $5 \mathrm{~min}$ and then analyzed for 4-HNE content by GC/MS. GC/ MS analysis was performed using a Focus GC coupled to a DSQ II mass spectrometer and an AS 3000 autosampler (Thermo Fisher).A15-m TR-5MS column (0.25$\mathrm{mm}$ i.d., $0.25-\mu \mathrm{m}$ film thickness; Thermo Fisher) was used with ultrahigh-purity helium as the carrier gas at a constant flow rate of $1.0 \mathrm{ml} / \mathrm{min}$. Two microliters of sample was injected into the $270^{\circ} \mathrm{C}$ inlet using split mode with an injection ratio of 10 and a split flow of 10 $\mathrm{ml} / \mathrm{min}$. The initial oven temperature was $100^{\circ} \mathrm{C}$ and then ramped to $200^{\circ} \mathrm{C}$ at $15^{\circ} \mathrm{C} / \mathrm{min}$, followed by an increase in temperature to $300^{\circ} \mathrm{C}$ at $30^{\circ} \mathrm{C} / \mathrm{min}$, and held for $1 \mathrm{~min}$. The MS transfer line temperature was held constant at $250^{\circ} \mathrm{C}$ and the quadrupole at $180^{\circ} \mathrm{C}$. Analysis was done by negative-ion chemical ionization using 2.5 $\mathrm{ml} / \mathrm{min}$ methane reagent gas. Ions were detected using SIM mode with a dwell time of $15.0 \mathrm{~ms}$ for each fragment of 4-HNE at $\mathrm{m} / \mathrm{z} 152,283$, and 303, and $\mathrm{d} 3-4$ $\mathrm{HNE}$ at $\mathrm{m} / \mathrm{z} 153,286$, and 306 . Under these conditions, the larger, second peak of the two 4-HNE isomers was used for quantification and exhibited a retention time of $7.18 \mathrm{~min}$, which was just preceded by the elution of d34-HNE at $7.17 \mathrm{~min}$. Quantification was performed using a standard curve generated by graphing the area ratio of 4-HNE to d3-4-HNE versus concentration.

\section{Measurement of glutathione (GSH and GSSG) in BAL fluid and cells}

BAL fluid from control, chlorine exposed and DMTU pre-treated chlorine exposed mice was collected for glutathione evaluation by HPLC. Both glutathione (GSH) and glutathione disulfide (GSSG) were measured to determine if GSH had converted to GSSG. As GSH is found almost exclusively in its reduced form, a conversion to GSSG, which his inducible following oxidative stress, would indicate an increase in oxidative stress in the lung. BAL samples were collected at 10 minutes, one hour and 24 hours after $\mathrm{Cl}_{2}$ challenge. Phosphoric acid $(60 \mu \mathrm{L} ; 1 \mathrm{M})$ was added to BALF samples to prevent GSH degradation. BAL was centrifuged at 1500 RPM for 5 minutes, and the supernatant was removed for evaluation of extracellular GSH/GSSG and $150 \mu \mathrm{L}$ of PBS and $15 \mu \mathrm{L} 1 \mathrm{M}$ phosphoric acid added was used to reconstitute the pellet for analysis of intracellular GSH and GSSG. CHAPPS $(150 \mu \mathrm{L} ; 6 \mathrm{mM})$ was added to lyse the cells. GSH and GSSG were measured by RP-HPLC using a post-column derivatization procedure modified from the literature [14]. GSH and GSSG levels were determined in $50 \mu \mathrm{l}$ aliquots by RP-HPLC using a gradient prepared from $0.05 \%$ trifluoroacetic acid (TFA) in water (solvent $\mathrm{C}$ ) and $0.05 \%$ TFA in acetonitrile (solvent D) as follows: $0 \mathrm{~min}, 0 \% \mathrm{D} ; 10 \mathrm{~min}, 15 \% \mathrm{D}$. The flow rate was $1 \mathrm{ml} / \mathrm{min}$ and the stationery phase was a column $(150 \times 4.6 \mathrm{~mm})$ of Ultracarb ODS (31\% carbon loading; $5 \mu \mathrm{m}$ particle size; $150 \times 4.6 \mathrm{~mm}$; Phenomenex, Torrance, CA). The eluate from the column was mixed with o-phthalaldehyde $(370 \mu \mathrm{M})$ in $0.2 \mathrm{M}$ tribasic sodium phosphate, $\mathrm{pH} 12$, which was pumped into a T-fitting using an auxiliary pump (Waters Reagent Manager). The mixture then passed through a loop of PEEK tubing $(6 \mathrm{~m} \times 0.5 \mathrm{~mm}$, i.d.; volume, $1.2 \mathrm{ml})$ that was placed in a water bath at $70^{\circ} \mathrm{C}$. Under these conditions both GSH and GSSG are converted to a fluorescent isoindole adduct, which is measured using excitation and emission wavelengths of 336 and $420 \mathrm{~nm}$, respectively. Prior to introduction into the fluorescence detector (Waters model 2475 Multi wavelength Fluorescence Detector), the mixture was cooled in a small ice-water bath and passed through a filter containing an OptiSolv $0.2 \mu \mathrm{m}$ frit (Optimize Technologies). The amounts of GSH and GSSG were determined from a standard curve using the authentic compounds as external standards.

\section{Statistical analysis}

Data were analyzed using an analysis of variance and for post hoc comparisons of means a Newman-Keuls test was used. A p $<0.05$ was accepted as significant. All values are expressed as the mean + one standard error of the mean.

\section{Results}

\section{Concentration-dependent changes in airway} responsiveness following $\mathrm{Cl}_{2}$

To establish a suitable submaximal concentration of $\mathrm{Cl}_{2}$ for subsequent experiments animals were exposed to $100 \mathrm{ppm}, 200 \mathrm{ppm}$ or $400 \mathrm{ppm}$ of $\mathrm{Cl}_{2}$ for 5 minutes. The next day, the animals were challenged with doubling doses of MCh ranging from 6.25 to $50 \mathrm{mg} / \mathrm{ml}$. Respiratory system resistance (Figure 1A) and elastance (Figure 1B) were evaluated. There was a dose-dependent increase in responsiveness to $\mathrm{MCh}$ reflected in both of the above parameters of lung function.

\section{Histological changes in the airways after $\mathrm{Cl}_{2}$ exposure}

The effects of $\mathrm{Cl}_{2}$ on airway architecture were assessed on hematoxylin and eosin stained lung sections obtained 24 hours after exposure (Figure 2). Lower concentrations of $\mathrm{Cl}_{2}(100 \mathrm{ppm}$ and $200 \mathrm{ppm})$ did not result in any detectable change under light microscopy to the airway epithelium (Figure $2 \mathrm{~A}$ and $2 \mathrm{~B}$ ). There was an obvious thinning of the airway epithelium at a 


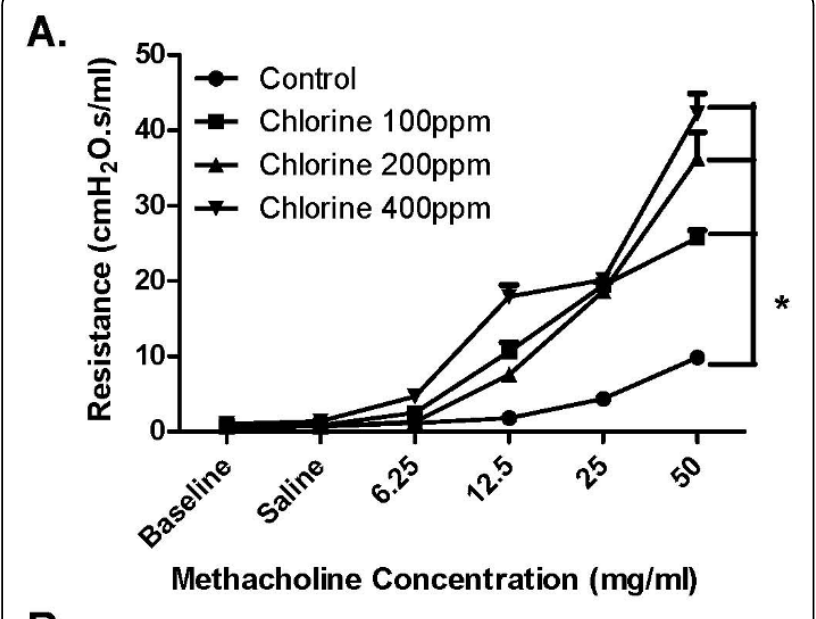

B.

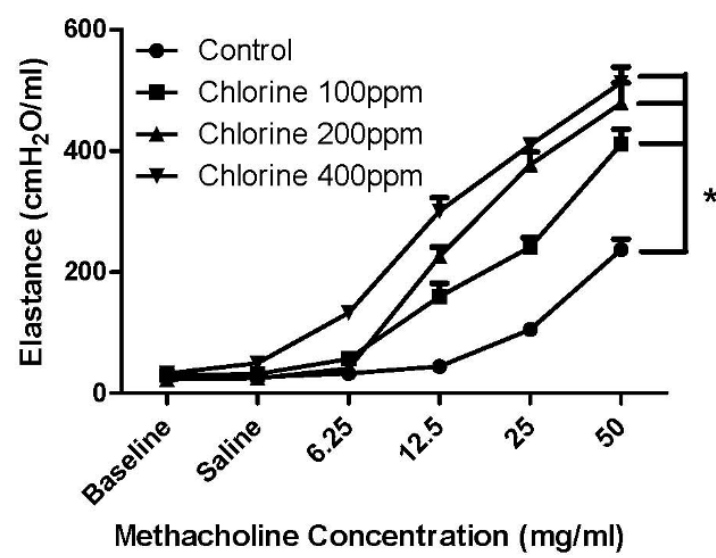

Figure 1 Dose-response effect of $\mathrm{Cl}_{2}$ on respiratory responsiveness to methacholine. Mice were either unchallenged (Control; $n=6)$ or challenged with $100(n=6), 200(n=6)$ or 400 $(n=6)$ ppm $\mathrm{Cl}_{2}$ gas. After $24 \mathrm{~h}$, total respiratory system resistance (A) and respiratory system elastance (B) in response to saline (Sal) and doubling doses of MCh were assessed using a small animal ventilator (FlexiVent). Baseline (Base) values obtained from untreated mice are shown for comparison. Mice treated with all three concentrations of $\mathrm{Cl}_{2}$ showed significantly higher respiratory system resistance and at $12.5,25$, and $50 \mathrm{mg} / \mathrm{ml}$ of MCh as compared with control. ${ }^{*} p<0.05, n=6$ per group.

concentration of $400 \mathrm{ppm}$ (Figure 2C). There were statistically significant differences observed in epithelial cell height caused by exposure to $\mathrm{Cl}_{2}$ (Fig 2E). We also quantified the number of epithelial cells in the airway walls. While there was no significant difference in cell following exposure to $\mathrm{Cl}_{2}$ at $100 \mathrm{ppm}$ compared to control (Figure 2D), at $400 \mathrm{ppm}$, there were fewer epithelial cells compared to both control and $100 \mathrm{ppm}$ (Fig 2D). Given the lack of gross histological change induced by $100 \mathrm{ppm}$ of $\mathrm{Cl}_{2}$ we chose to perform further studies using this concentration.
Effect of DMTU on MCh responsiveness following $\mathrm{Cl}_{2}$ challenge

Airway responses to increasing doses of $\mathrm{MCh}(6.25-50 \mathrm{mg} /$ $\mathrm{ml}$ ) were elevated $24 \mathrm{~h}$ following $\mathrm{Cl}_{2}$ challenge (Figure $3 \mathrm{~A}$ ). This effect was attenuated by administration of DMTU given both prior to and post $\mathrm{Cl}_{2}$-exposure. Changes in respiratory system elastance in response to $\mathrm{MCh}$ paralleled those observed for resistance (Figure 3B). DMTU alone had no significant effect on $\mathrm{MCh}$ responsiveness.

\section{Changes in bronchoalveolar lavage cells after $\mathrm{Cl}_{2}$ gas exposure}

To assess the effects of $\mathrm{Cl}_{2}$ on airway inflammation and epithelial cell shedding bronchoalveolar lavage was performed at 10 minutes, one hour and at 24 hours after $\mathrm{Cl}_{2}$ exposure. The fluid recovered by BAL averaged $75 \%$ of the volume instilled and did not differ significantly among the groups. Total cell counts were not significantly different at 10 minutes after exposure to $\mathrm{Cl}_{2}$ (Figure 4A) but were significantly increased in $\mathrm{Cl}_{2}$ treated groups by one and 24 hours compared to control (Figure 4B and 4C). At one hour, pre-treatment with DMTU reduced the total number of inflammatory cells present in the airways compared to $\mathrm{Cl}_{2}$ only mice. At 24 hours, total cell counts were persistently elevated after $\mathrm{Cl}_{2}$ and were attenuated only in mice post-treated with DMTU after $\mathrm{Cl}_{2}$ exposure (Figure $4 \mathrm{C}$ ). $\mathrm{Cl}_{2}$ caused a significant increase in neutrophils and lymphocytes 24 hours following challenge, an effect attenuated by both pre- and post-treatment with DMTU (Figure 5C and 5D). There were no significant changes in any of the cell subsets at 10 mins (Figure 5A, B and 5E).

\section{Changes in protein level following $\mathrm{Cl}_{2}$ exposure}

We measured the total protein level in BAL fluid harvested at 1 and 24 hours after $\mathrm{Cl}_{2}$ exposure to assess the effects of $\mathrm{Cl}_{2}$ on cell damage and protein levels. At both time points following $\mathrm{Cl}_{2}$ exposure there was a significant increase in total protein in the BAL fluid as assessed by the Bradford assay. Treatment with DMTU, both before and after $\mathrm{Cl}_{2}$ exposure reduced protein levels in BAL (Figure 6).

\section{Effects of $\mathrm{Cl}_{2}$ on markers of oxidative stress}

Nitric oxide concentrations were determined using the Griess reaction and no significant change was seen between any of groups 24 hours following $\mathrm{Cl}_{2}$ challenge (Figure 7A). An OxyBlot was performed on lung extracts to detect proteins modified by oxygen metabolites 24 hours following $\mathrm{Cl}_{2}$ exposure. Levels of carbonylation were quantified by densitometry and no substantial difference was seen among control, $\mathrm{Cl}_{2}$ treated or DMTU treated animals (Figure 7B). Lungs were removed 24 hours following $\mathrm{Cl}_{2}$ treatment for analysis of 4-HNE by GC-MS. $\mathrm{Cl}_{2}$ induced a significant increase in 4-HNE 


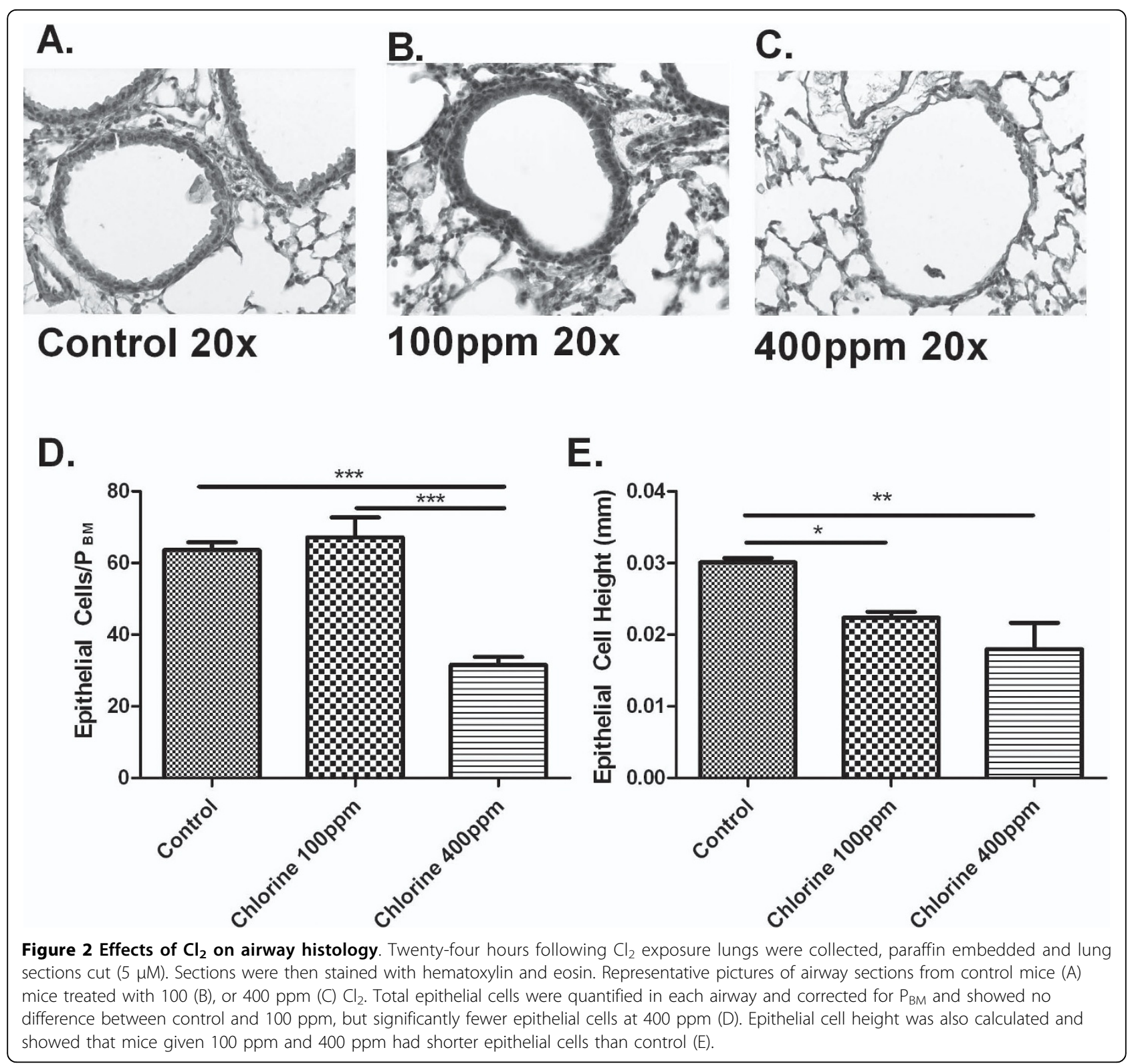

levels (Figure 7C). DMTU given either pre- or post- $\mathrm{Cl}_{2}$ treatment prevented any significant changes in 4-HNE levels (Figure 7C).

\section{Effects of $\mathrm{Cl}_{2}$ and DMTU treatments on GSH and GSSG} intracellularly and extracellularly in the bronchoalveolar compartment

$\mathrm{Cl}_{2}$ increased both intracellular (Figure 8A) and extracellular (Figure 8B) GSH levels in BAL after $10 \mathrm{~min}$, but had no effect on GSH levels after 1 and 24 hours (Figure $8 \mathrm{C}$ and $8 \mathrm{D})$. Treatment with DMTU prior to administration of $\mathrm{Cl}_{2}$ blocked the increase in $\mathrm{GSH}$ in both compartments at $10 \mathrm{~min}$ (Figure $8 \mathrm{~A}$ and $8 \mathrm{~B}$ ) but had no effect on GSH levels at the later time points (Figure $8 \mathrm{C}$ and $8 \mathrm{D}$ ). $\mathrm{Cl}_{2}$ induced a significant increase in GSSG levels in the intracellular and extracellular compartments at $10 \mathrm{~min}$ (Figure 9A and 9B). At 1 and 24 hours there was a decrease in GSSG levels in $\mathrm{Cl}_{2}$ treated groups compared to control and DMTU treated groups that were restored by DMTU treatment (Figure 9C and 9D). The ratio of GSH/GSSG was significantly higher in the cell fraction of BAL in $\mathrm{Cl}_{2}$ exposed mice than control and DMTU treated mice at 10 minutes (Figure 10A). There was a trend towards a decrease in GSH/GSSG ratio in the extracellular compartment of the BAL at the same time point, but this was not statistically significant. Additionally, at 24 hours, the GSH/GSSG ratio remained high in the $\mathrm{Cl}_{2}$ treated mice but was attributable to a decline in GSSG at this time (Figure 10D). This effect was prevented by treatment with DMTU (Figure 10A and 10D). 


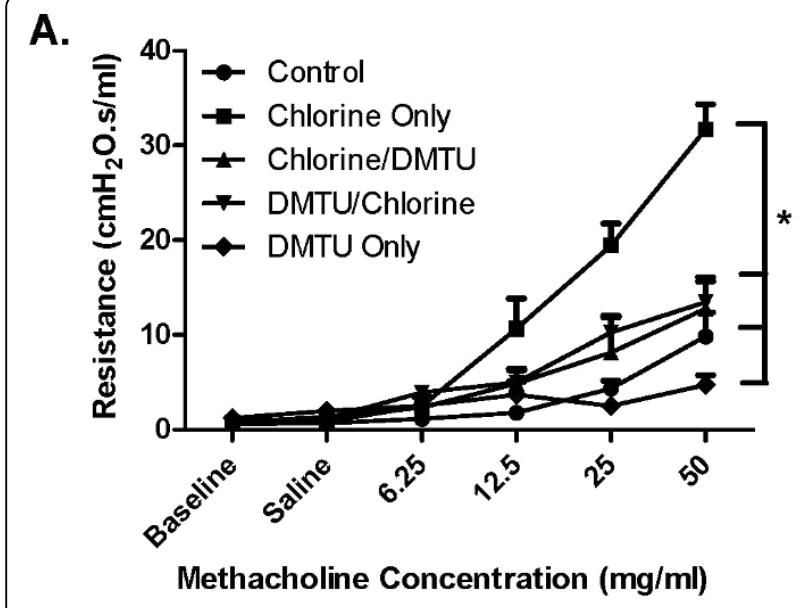

B.

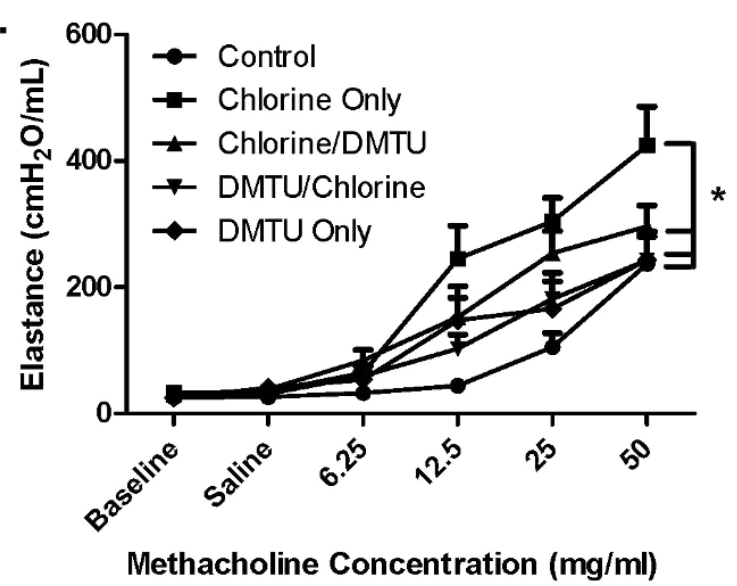

Figure 3 Effects of $\mathrm{Cl}_{2}$ on methacholine respiratory system resistance and elastance. Panel A shows the effects of $\mathrm{Cl}_{2}$ exposure on total respiratory system resistance in mice that were treated with before and 1 hour after exposure with DMTU. A twoway ANOVA showed that there is a significant difference between mice pre- or post-treated with DMTU when compared to animals receiving $\mathrm{Cl}_{2}$ only. Panel $\mathrm{B}$ shows the effects of $\mathrm{Cl}_{2}$ exposure and DMTU treatment on total respiratory system elastance. DMTU/Cl treated animals had elastance levels similar to control whereas $\mathrm{Cl}_{2}$ only treated mice had significantly higher values compared to control: $\mathrm{n}=6$ per group; $^{*} \mathrm{p}<0.05$.

\section{Discussion}

In the current study we have shown that Balb/C mice exposed to $\mathrm{Cl}_{2}$ gas for 5 min develop concentrationdependent airway hyperresponsiveness to inhaled aerosolized $\mathrm{MCh}$. At concentrations of $\mathrm{Cl}_{2}$ greater than 100 ppm there is evidence of epithelial damage with flattening of the cells and the shedding of ciliated cells into the bronchoalveolar lavage fluid. However, at a concentration of $\mathrm{Cl}_{2}$ (100 ppm), despite the lack of gross morphological changes in epithelial cells there was still a substantial degree of airway hyperresponsiveness, an effect potentially attributable to increased oxidative stress. The effect of $\mathrm{Cl}_{2}$ on airway function was attenuated by

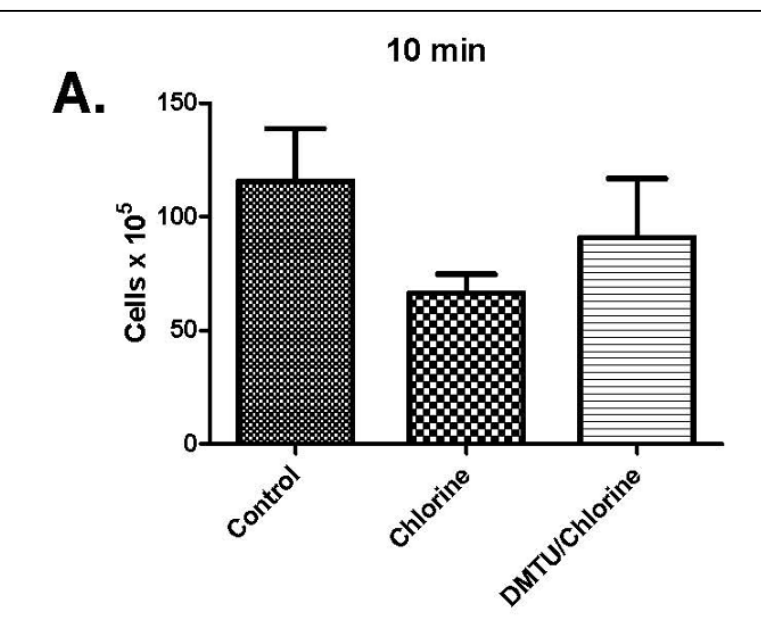

B.

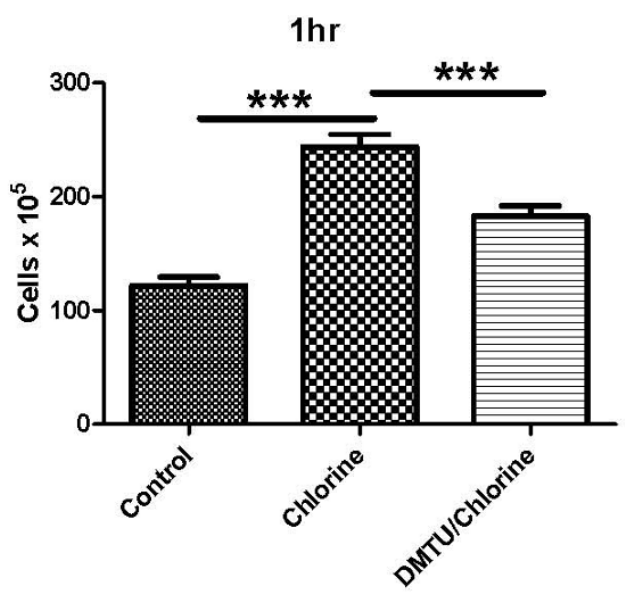

C.

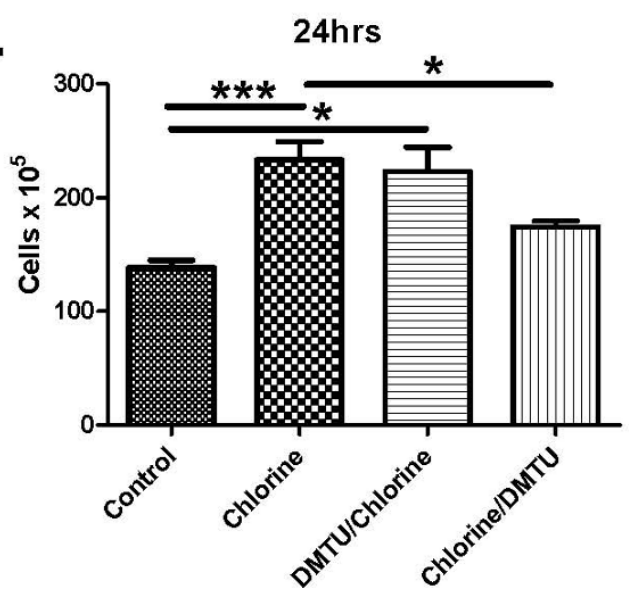

Figure 4 Effects of $\mathrm{Cl}_{2}$ exposure on the numbers of cells in BAL fluid. Data for control and $\mathrm{Cl}_{2}$ exposed animals that were sacrificed 10 minutes (A), 1 hour (B) and 24 hours (C) after $\mathrm{Cl}_{2}$ exposure. $\mathrm{Cl}_{2}$ exposure caused a significant increase in total leukocytes compared to controls at 1 hour and 24 hours, the effect of which was attenuated by pre-treatment with DMTU at one hour and post treatment with DMTU at 24 hours. $\left(n=6\right.$ per group; ${ }^{*} p<$ 0.05., $\left.{ }^{* *} p<0.01,{ }^{* * *} p<0.001\right)$. 


\section{A.}

Macrophages $24 \mathrm{~h}$

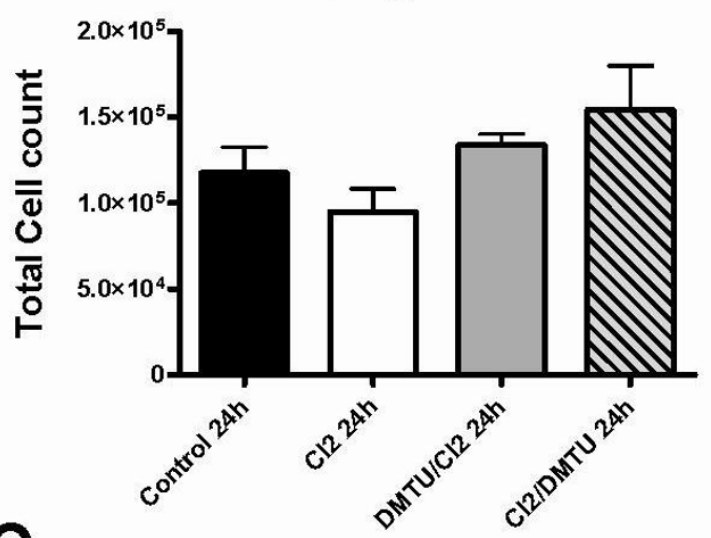

C.

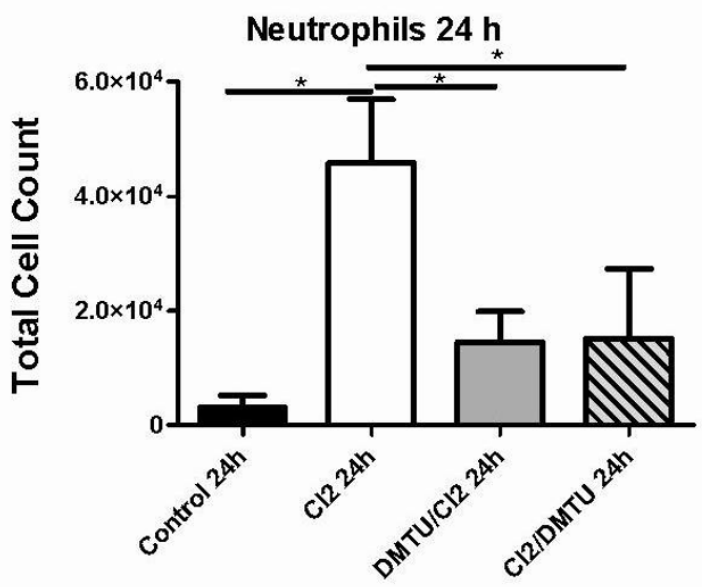

E.

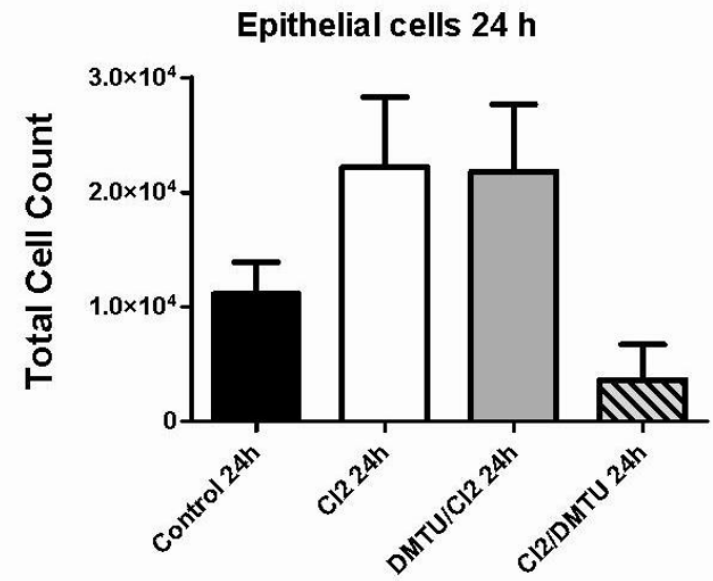

Figure 5 Cellular composition of BAL fluid following $\mathrm{Cl}_{2}$ exposure. Differential cell counts were done at 10 minutes and 24 hours. No cell subset was significantly different at $10 \mathrm{~min}$ (data not shown). At 24 hours neutrophils and lymphocytes were significantly elevated in $\mathrm{Cl}_{2} \mathrm{groups}$. Treatment with DMTU was limited increases in these cell types. There was no difference between control and DMTU treated groups. Control $(n=9), C_{2} 100 \mathrm{ppm}(n=7), \mathrm{DMTU} \mathrm{Cl}_{2}(\mathrm{n}=7), \mathrm{Cl}_{2} / \mathrm{DMTU}(\mathrm{n}=6){ }^{*}<0.05$. 


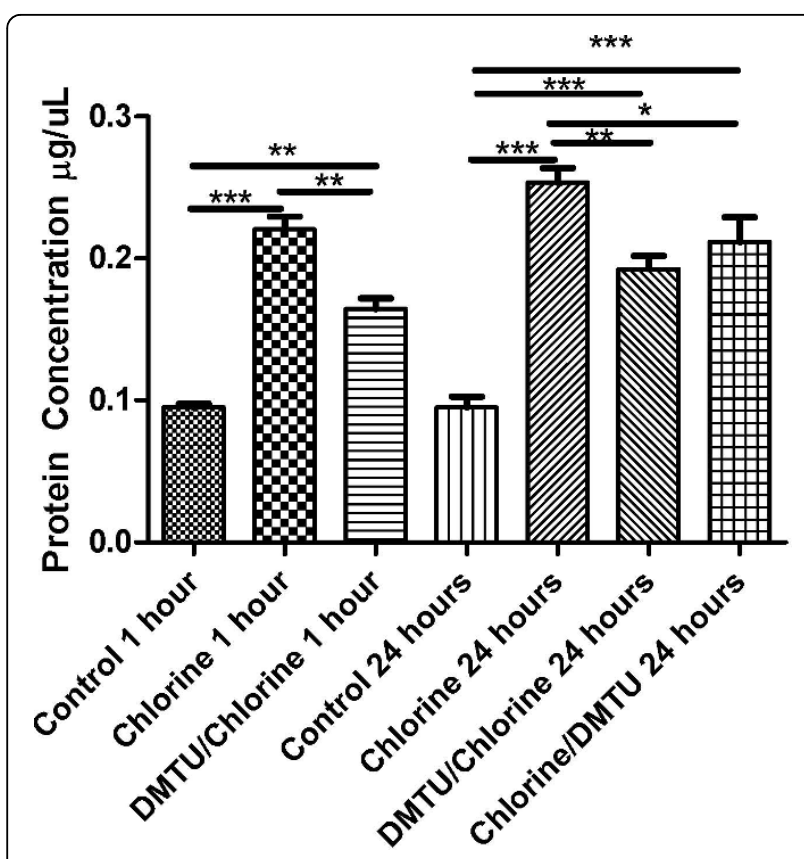

Figure 6 Effects of $\mathrm{Cl}_{2}$ exposure and DMTU treatment on BAL fluid protein. Protein levels in BAL fluid were assessed by Bradford assay. There was a significant increase in total protein at 1 and 24 hours after $\mathrm{Cl}_{2}$ exposure. Pre-treatment with DMTU attenuated the increase in protein at both time points and at 24 hours when given one hour post- $\mathrm{Cl}_{2}$ exposure. ( $n=6-9 /$ group; ${ }^{*} \mathrm{p}<0.05$, ${ }^{* *} p<0.01$, $\left.*^{* * *} p<0.001\right)$

pre-treating the mice one hour before $\mathrm{Cl}_{2}$ exposure with an intraperitoneal injection of DMTU. Treatment with DMTU 1 hour after exposure to $\mathrm{Cl}_{2}$ also ameliorated the adverse effects on airway function. Oxidative injury to lung tissue was detected 24 hours post- $\mathrm{Cl}_{2}$ exposure and indicated by and increase lipid peroxidation in $\mathrm{Cl}_{2}$ exposed mice, an effect attenuated by preor post $-\mathrm{Cl}_{2}$ treatment with DMTU. Additionally, DMTU treatment maintained GSH/GSSG levels at those of control mice, whereas $\mathrm{Cl}_{2}$ only treated mice showed significant changes in both GSH and GSSG at various time points.

Airway hyperresponsiveness has been previously demonstrated to follow $\mathrm{Cl}_{2}$ exposure in both rat and mouse models of irritant induced asthma $[15,16]$. Pathological changes including airway remodeling occur following a single exposure to a high concentration of $\mathrm{Cl}_{2}$ in rats [17]. It seems likely that epithelial damage is a major contributor to the altered responsiveness to inhaled MCh. The epithelium could serve as a barrier that could reduce access of MCh to the smooth muscle or might attenuate the responsiveness to MCh through the release of relaxant substances such as NO or prostaglandins [18-20]. The mechanism of AHR following $\mathrm{Cl}_{2}$ may be similar to that of ozone in that both forms of injury are associated with oxidant damage to the tissues.
Natural killer cells and interleukin-17 have been shown recently to be essential in the protection against airway damage and hyperresponsiveness following repeated ozone exposures [21]. $\mathrm{Cl}_{2}$ potentially causes toxicity through its highly reactive nature. However, it is also know to cause damage through the generation of hydrochloric acid $(\mathrm{HCl})$. Indeed $\mathrm{HCl}$ has been shown to cause airway hyperresponsiveness in mice when administered into the airways, by mechanisms that have been suggested to relate to epithelial barrier function. However, it has been shown that $\mathrm{HCl}$ is much less toxic than $\mathrm{Cl}_{2}$ so it is likely that the effects of $\mathrm{Cl}_{2}$ induced oxidants are more likely to account for its adverse effects [22,7].

Irrespective of the mechanism of $\mathrm{Cl}_{2}$ induced airway hyperresponsiveness, DMTU was highly effective in preventing its development when given either as a pretreatment or as a rescue treatment. Assuming that the therapeutic effects of DMTU are indeed mediated by anti-oxidant properties, the data suggest that the initial direct oxidative stress caused by $\mathrm{Cl}_{2}$ is only part of the oxidative burden and that another source of reactive oxygen is important in the time period between 1 and $24 \mathrm{~h}$ following $\mathrm{Cl}_{2}$ exposure. For example, secondary activation of neutrophils, macrophages or epithelium and various chemokines, cytokines and growth factors they secrete could conceivably contribute to airway damage in a mechanism similar those shown for respiratory viral infection [23].

Measures of oxidant injury such as nitric oxide production, as reflected in BAL nitrates/nitrites, and protein carbonylation were not detectably different from control animals at 24 hours after $\mathrm{Cl}_{2}$ exposure, consistent with a relatively mild injury compared to previous results [7]. However, presence of oxidative stress was apparent following assessment of lung tissue levels of 4-HNE, an indication of lipid peroxidation. 4-HNE levels were reduced to baseline by pre- and post- $\mathrm{Cl}_{2}$ treatment with DMTU, suggesting that lipid peroxidation is a prolonged effect of exposure to $\mathrm{Cl}_{2}$ further supporting the conclusion that the amelioration of markers of airway injury is likely mediated by anti-oxidant properties of DMTU.

Glutathione is an important endogenous antioxidant and changes in its intracellular and extracellular concentrations are expected following an oxidant challenge such as $\mathrm{Cl}_{2}$. Generally oxidant stress is noted to diminish GSH both intracellularly and extracellularly in the lung (reviewed in [24]) although glutathione increases as an adaptive response to oxidative stress associated for example with cigarette smoking or pulmonary infection $[25,26]$. We found that $\mathrm{Cl}_{2}$ exposure induced rapid and transient changes in glutathione concentrations. Ten minutes following exposure there was a surge in both intra- and extra-cellular GSH levels in BAL, presumably attributable to GSH synthesis and export into the 


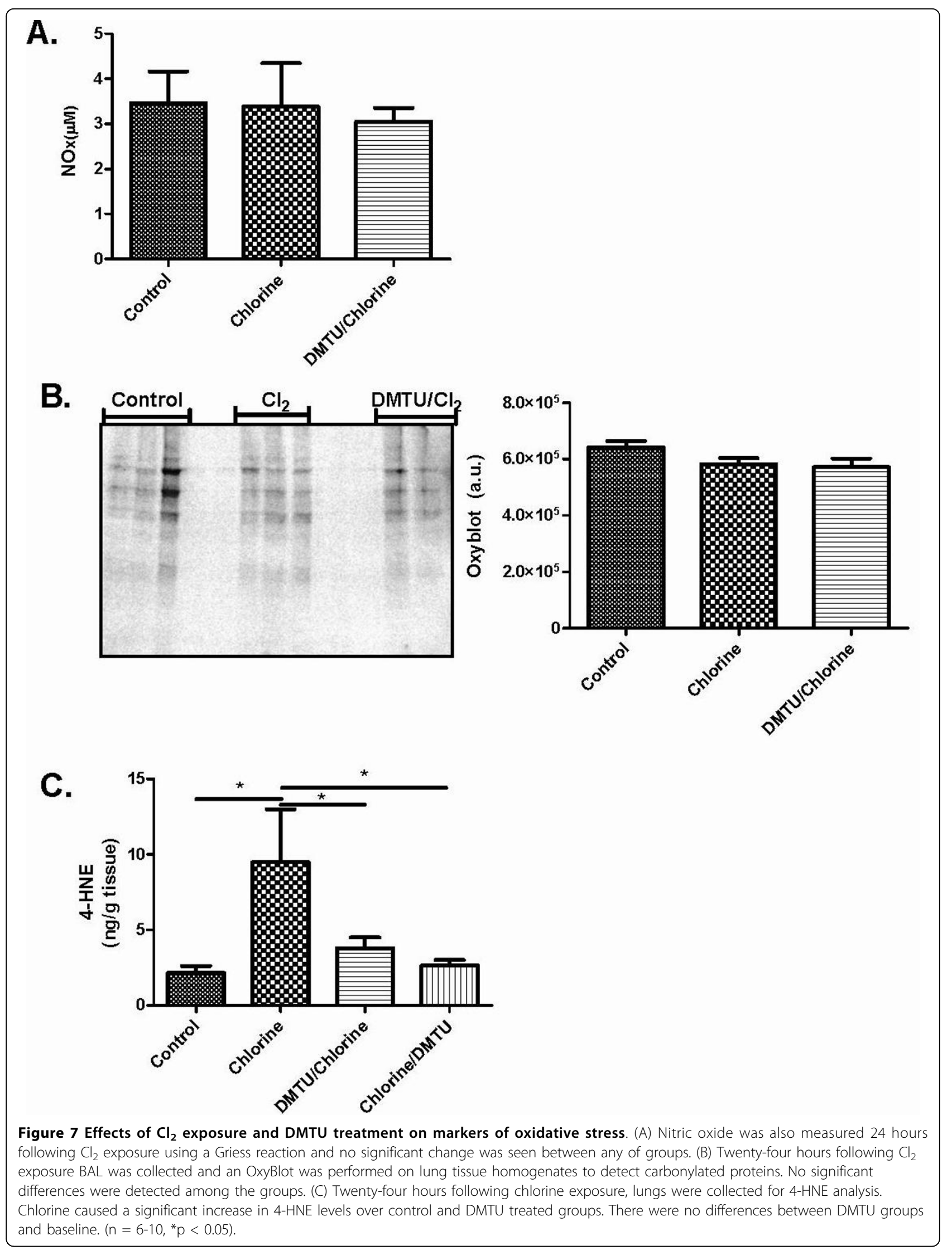




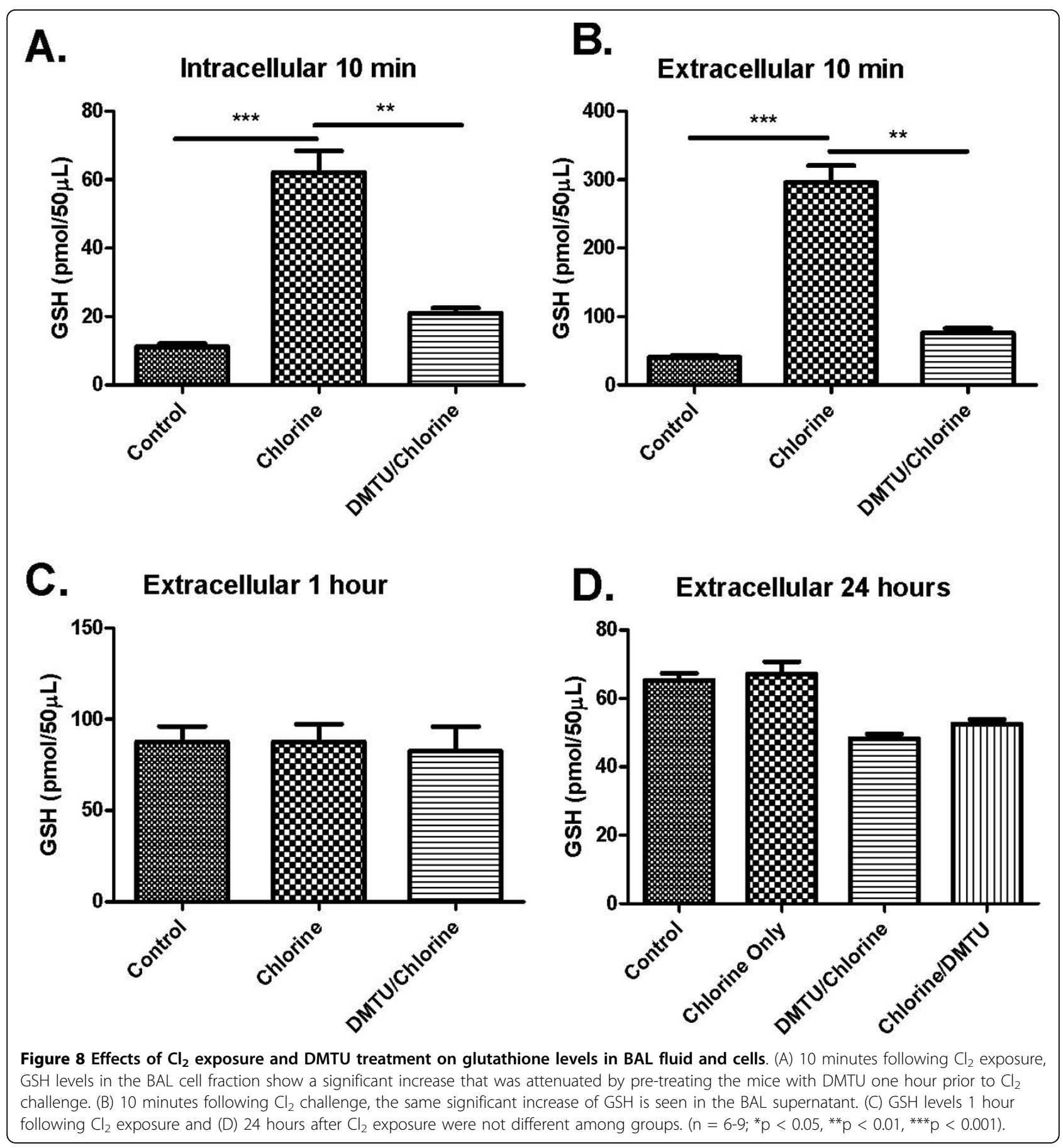

extracellular milieu. Additionally, $\mathrm{Cl}_{2}$ may induce lysis of pulmonary cells, especially epithelial cells which might also contribute to the large amount of extracellular GSH. Epithelial cells are known to contain high levels of GSH [25] and high doses of $\mathrm{Cl}_{2}$ have been shown to cause epithelial cell shedding and/or lysis. However the changes in GSH observed in the current experiment occurred in the absence of significant changes in epithelial cell counts in BAL fluid or in epithelial cell numbers enumerated in the airway walls themselves. The changes in GSH were transient and had resolved by 1 hour. The rapid rise in $\mathrm{GSH}$ was prevented by pre-treatment with DMTU prior to $\mathrm{Cl}_{2}$ exposure, suggesting a measure of relief against the effects of oxidative stress.

In addition to the early spike in GSH concentration in BAL cells and fluid, we also noted a significant increase in GSH in its oxidized form, glutathione disulfide (GSSG), both intra-and exrtacellularly at 10 minutes, 


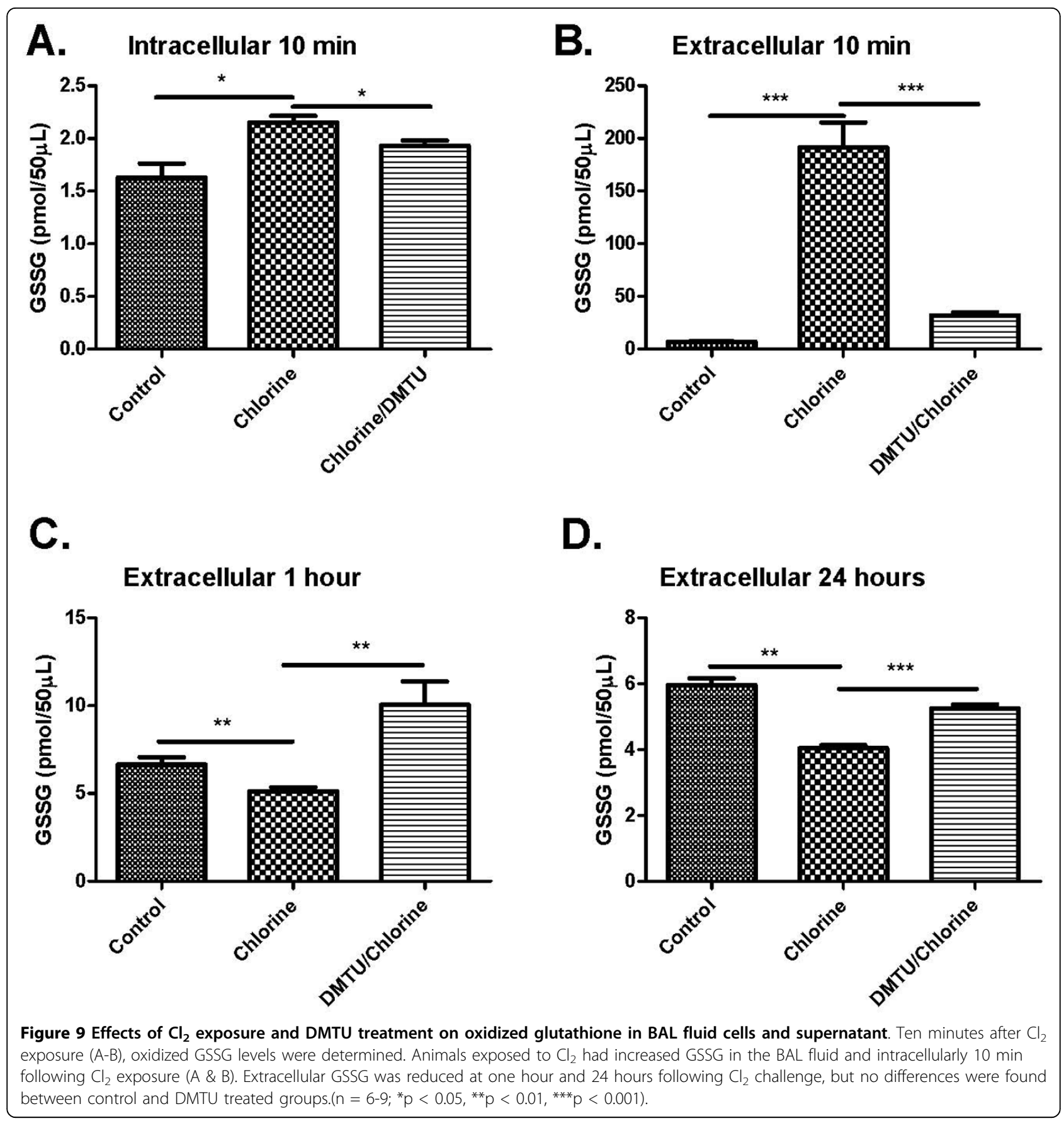

presumably indicative of oxidative stress in the lung. These changes were abrogated by DMTU supporting the idea that the mechanism of protection was through neutralization of oxygen metabolites. Furthermore, the protection provided by delayed treatment with DMTU further suggests that delayed oxidative stress is also a significant contributor to the response to injury. By 1 and 24 hours, GSH levels were restored but GSSG levels showed a significant decrease in chlorine exposed groups. It is not clear what the significance of this finding is for airway function. Despite the GSSG levels being depleted at this time point, the ratio of GSH/ GSSG was higher in chlorine exposed mice compared with controls and DMTU treated animals. The antioxidants ascorbic acid, desferroxamine and N-acetyl-Lcysteine have been show to ameliorate the injury caused by $\mathrm{Cl}_{2}$ in the rat [9]. In these experiments there was evidence of depletion of GSH by $\mathrm{Cl}_{2}$, an observation that we have not confirmed. However the exposure in the rat was substantially greater (400 ppm for 30 minutes). 


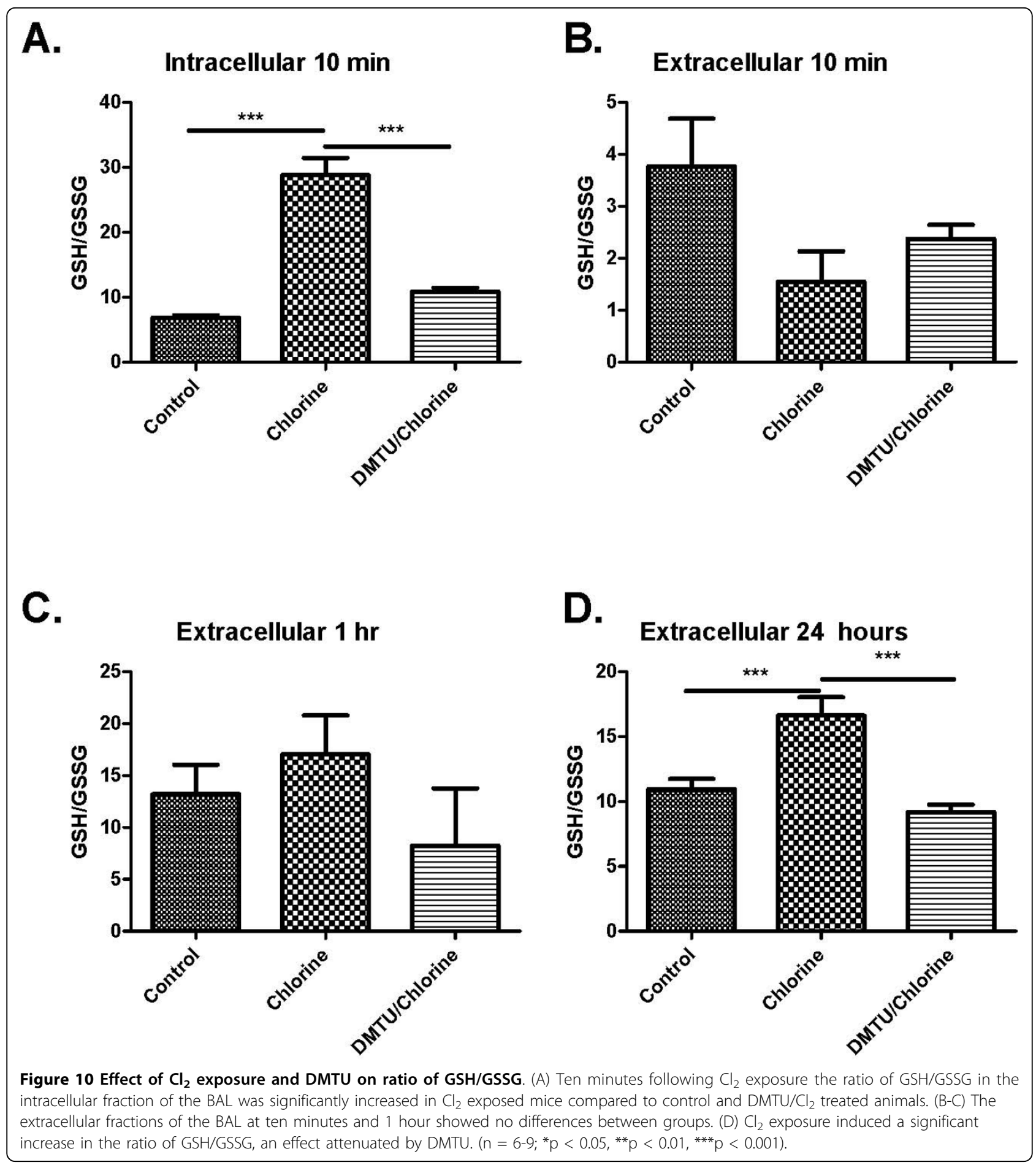

Consideration of oxidative stress as a target in irritantinduced asthma caused by potent oxidants is reasonable. However, oxidative stress-induced damage may also contribute to other forms of asthma. Asthmatic subjects manifest evidence of oxidative stress, as evidenced by a variety of changes including increased superoxide generation from leukocytes, increased total nitrites and nitrates, increased protein carbonyls, increased nitric oxide in exhaled breath condensate, increased lipid peroxidation products and decreased protein sulfhydryls in plasma [26]. They also show increased superoxide dismutase activity in red blood cells, increased total blood glutathione, and decreased glutathione peroxidase activity in red blood cells and leukocytes. A recent 
epidemiological study of childhood asthma demonstrated significant decreases in glutathione and amino acid precursors of glutathione as well as various other components of both enzymatic and non-enzymatic endogenous antioxidant defense mechanisms [27]. Thioredoxin, a reducing protein, may also inhibit experimental allergic asthma and airway remodeling [28].

In conclusion, exposure to modest levels of $\mathrm{Cl}_{2}$ (100 $\mathrm{ppm}$ ) leads to an increase in airway responsiveness in mice. Mice exposed to $\mathrm{Cl}_{2}$ showed increases in total inflammatory cells, in particular neutrophils and lymphocytes. Despite lack of increases in nitrate/nitrite or carbonylated proteins, lipid peroxidation levels (4-HNE) were significantly higher in $\mathrm{Cl}_{2}$ exposed animals. Importantly, there was also evidence of a salutary treatment effect when DMTU was administered as late as 1 hour after the exposure to $\mathrm{Cl}_{2}$ suggesting that oxidative damage is an ongoing process following the initial injury. Treatment with anti-oxidants shortly after acute exposure to highly irritant oxidant substances such as $\mathrm{Cl}_{2}$ may have therapeutic utility.

\section{Acknowledgements}

Supported by grants from the Institut de recherche Robert-Sauvé en santé et en sécurité du travail and the Canadian Institutes of Health Research (MOP 77749).

The research is supported by the CounterACT program, National Institutes of health Office of the Director, and National Institute of Health Enviornmental Science, Grant number U4 ESO15678 (CWW, BJD, JGM, TM).

\section{Author details}

'Meakins Christie Laboratories, Department of Medicine, McGill University, Montreal, Quebec, Canada. ${ }^{2}$ Department of Pediatrics, National Jewish Health, Denver, Colorado, USA.

\section{Authors' contributions}

TM participated in the study design and performed the experiments for Figures 1, 2, 3, 4, 5, 6 in their entirety and harvested materials for analyses in Figures $7,8,9,10$. She also wrote the manuscript. WP contributed through the analyses of GSH and GSSG and assisted with the writing of the manuscript. BD and CW contributed to the revision of the paper and provided the analysis of $4-\mathrm{HNE}$. KG performed the measurements of NOx and approved the manuscript. HKQ provided critical review of the paper and assistance with data analysis. NL assisted in the setup of chlorine exposure and in supervising the exposure of animals in a safe manner. JJT assisted with analysis of biological samples. JGM was involved in the study design, in review of the data and in the preparation of the manuscript. All authors read and approved the final manuscript.

\section{Competing interests}

The authors declare that they have no competing interests.

Received: 26 February 2010 Accepted: 6 October 2010 Published: 6 October 2010

\section{References}

1. Henneberger PK, Olin AC, Andersson E, Hagberg S, Toren K: The incidence of respiratory symptoms and diseases among pulp mill workers with peak exposures to ozone and other irritant gases. Chest 2005, 128:3028.

2. Brooks SM, Weiss MA, Bernstein IL: Reactive airways dysfunction syndrome (RADS). Persistent asthma syndrome after high level irritant exposures. Chest 1985, 88:376.
3. Deschamps D, Soler P, Rosenberg N, Baud F, Gervais P: Persistent Asthma After Inhalation of A Mixture of Sodium-Hypochlorite and HydrochloricAcid. Chest 1994, 105:1895

4. Van SD, Wenck MA, Belflower A, Drociuk D, Ferdinands J, Holguin F, Svendsen E, Bretous L, Jankelevich S, Gibson JJ, Garbe P, Moolenaar RL: Acute health effects after exposure to chlorine gas released after a train derailment. Am J Emerg Med 2009, 27:1.

5. Lemiere C, Malo JL, Boutet M: Reactive airways dysfunction syndrome due to chlorine: sequential bronchial biopsies and functional assessment. Eur Respir J 1997, 10:241.

6. Jia Y, Xu L, Turner DJ, Martin JG: Endogenous nitric oxide contributes to strain-related differences in airway responsiveness in rats. J Appl Physiol 1996, 80:404.

7. Martin JG, Campbell HR, lijima H, Gautrin D, Malo JL, Eidelman DH, Hamid Q, Maghni K: Chlorine-induced injury to the airways in mice. Am J Respir Crit Care Med 2003, 168:568.

8. Cheek JM, Mcdonald RJ, Rapalyea L, Tarkington BK, Hyde DM: Neutrophils Enhance Removal of Ozone-Injured Alveolar Epithelial-Cells In-Vitro. American Journal of Physiology-Lung Cellular and Molecular Physiology 1995, 13:L527-L535.

9. Leustik M, Doran S, Bracher A, Williams S, Squadrito GL, Schoeb TR, Postlethwait $E$, Matalon S: Mitigation of chlorine-induced lung injury by low-molecular-weight antioxidants. Am J Physiol Lung Cell Mol Physiol 2008, 295:L733-L743.

10. Jackson JH, White CW, Parker NB, Ryan JW, Repine JE: Dimethylthiourea consumption reflects $\mathrm{H} 2 \mathrm{O} 2$ concentrations and severity of acute lung injury. J Appl Physiol 1985, 59(6):1995-8.

11. Day BJ, van Heeckeren AM, Min E, Velsor LW: Role for cystic fibrosis transmembrane conductance regulator protein in a glutathione response to bronchopulmonary pseudomonas infection. Infect Immun 2004, 72:2045.

12. Hamada K, Goldsmith CA, Kobzik L: Increased airway hyperresponsiveness and inflammation in a juvenile mouse model of asthma exposed to airpollutant aerosol. Journal of Toxicology and Environmental Health-Part A 1999, 58:129.

13. Parmentier C, Leroy P, Wellman M, Nicolas A: Determination of cellular thiols and glutathione-related enzyme activities: versatility of highperformance liquid chromatography-spectrofluorimetric detection. J Chromatogr B Biomed Sci Appl 1998, 719:37.

14. Pichavant M, Goya S, Meyer EH, Johnston RA, Kim HY, Matangkasombut $P$, Zhu M, Iwakura Y, Savage PB, Dekruyff RH, Shore SA, Umetsu DT: Ozone exposure in a mouse model induces airway hyperreactivity that requires the presence of natural killer T cells and IL-17. J Exp Med 2008, 205:385.

15. Demnati R, Fraser R, Ghezzo H, Martin JG, Plaa G, Malo JL: Time-course of functional and pathological changes after a single high acute inhalation of chlorine in rats. Eur Respir J 1998, 11:922.

16. Koohsari H, Tamaoka M, Campbell HR, Martin JG: The role of gamma delta T cells in airway epithelial injury and bronchial responsiveness after chlorine gas exposure in mice. Respir Res 2007, 8:21.

17. Demnati R, Fraser R, Plaa G, Malo JL: Histopathological effects of acute exposure to chlorine gas on Sprague-Dawley rat lungs. J Environ Pathol Toxicol Oncol 1995, 14:15.

18. Jongejan R, De Jongste J, Raatgeep R, Stijnen T, Bonta I, Kerrebijn K: Effect of epithelial denudation, inflammatory mediators and mast cell activation on the sensitivity of isolated human airways to methacholine. Eur J Pharmacol 1991, 203:187.

19. Morrison KJ, Gao Y, Vanhoutte PM: Epithelial modulation of airway smooth muscle. [Review]. Am J Physiol 1990, 258:L254-L262.

20. Xie Z, Hakoda H, Ito Y: Airway epithelial cells regulate membrane potential, neurotransmission and muscle tone of the dog airway smooth muscle. J Physiol (Lond) 1992, 449:619.

21. Cantin AM, North SL, Hubbard RC, Crystal RG: Normal alveolar epithelial lining fluid contains high levels of glutathione. J Appl Physiol 1987, 63:152.

22. Rahman I, Macnee W: Oxidative stress and regulation of glutathione in lung inflammation. Eur Respir J 2000, 16:534.

23. Kariya C, Leitner $H$, Min $E$, van $H C$, van HA, Day BJ: A role for CFTR in the elevation of glutathione levels in the lung by oral glutathione administration. Am J Physiol Lung Cell Mol Physiol 2007, 292:L1590-L1597. 
24. Allen GB, Leclair TR, von RJ, Larrabee YC, Cloutier ME, Irvin CG, Bates JHT: Acid aspiration-induced airways hyperresponsiveness in mice. J Appl Physiol 2009, 107:1763-70.

25. Fox RB: Prevention of granulocyte-mediated oxidant lung injury in rats by a hydroxyl radical scavenger, dimethylthiourea. J Clin Invest 1984, 74:1456.

26. Wang SZ, Xu H, Wraith A, Bowden JJ, Alpers JH, Forsyth KD: Neutrophils induce damage to respiratory epithelial cells infected with respiratory syncytial virus. Eur Respir J 1998, 12:612.

27. Nadeem A, Chhabra SK, Masood A, Raj HG: Increased oxidative stress and altered levels of antioxidants in asthma. J Allergy Clin Immunol 2003, 111:72.

28. Sackesen C, Ercan H, Dizdar E, Soyer O, Gumus P, Tosun BN, Buyuktuncer Z, Karabulut E, Besler T, Kalayci O: A comprehensive evaluation of the enzymatic and nonenzymatic antioxidant systems in childhood asthma. J Allergy Clin Immunol 2008, 122(1):78-85.

doi:10.1186/1465-9921-11-138

Cite this article as: McGovern et al:: Dimethylthiourea protects against chlorine induced changes in airway function in a murine model of irritant induced asthma. Respiratory Research 2010 11:138.

\section{Submit your next manuscript to BioMed Central} and take full advantage of:

- Convenient online submission

- Thorough peer review

- No space constraints or color figure charges

- Immediate publication on acceptance

- Inclusion in PubMed, CAS, Scopus and Google Scholar

- Research which is freely available for redistribution

Submit your manuscript at www.biomedcentral.com/submit 